\title{
PERFORMANCES OF SAFT LITHIUM-ION CELLS IN LEO CYCLING
}

\author{
D. Prevot $^{(1)}$, Y. Borthomieu ${ }^{(1)}$, E. Ligneel ${ }^{(1)}$, R. Hague ${ }^{(1)}$, J-P. Peres ${ }^{(1)}$, C. Cenac-Morthe ${ }^{(2)}$ \\ (1) Saft Space and Defence Division BP 1039, 86060 Poitiers, France, \\ Yannick.Borthomieu@saftbatteries.com,Didier.Prevot@saftbatteries.com,Eric.Ligneel@saftbatteries.com, \\ Richard.Hague@saftbatteries.com,Jean-paul.Peres@saftbatteries.com
}

(2) CNES, 18 avenue Edouard Belin, 31401 Toulouse Cedex9, France, Celine.Cenac-Morthe@cnes.fr

\begin{abstract}
Based on good LEO lifetime tests results, Saft proposes currently VES16 Lithium-ion for 12 years mission in Low Earth Orbit (LEO) up to $30 \% \mathrm{DoD}$ or more within a temperature range from $+10^{\circ} \mathrm{C}$ to $+30^{\circ} \mathrm{C}$.

The first flight experimentation started at the end of 2015, confirming its ability to withstand the environmental stresses induced by a space launch and the in-flight constraints generated by a LEO mission.

The upcoming launches scheduled from 2016 will significantly increase the flight heritage of this cell.

From the beginning of VES16 Lithium-ion cell development, a wide lifetime tests program has been implemented in order to evaluate the different degradation modes due to the conditions applied in LEO cycling, as presented in Table 1 .

This program has allowed assessing the influence of different parameters such as EOCV (End Of Charge Voltage), DoD (Depth of Discharge), charge current and temperature.
\end{abstract}

New MP176065 XTD Lithium-ion cell, developed \& qualified by $\mathrm{Saft}$, with an operating range extended from $-40^{\circ} \mathrm{C}$ to $+85^{\circ} \mathrm{C}$, has already been selected for EXOMARS Rover mission.

Promising results in accelerated LEO cycling conditions at $30 \%$ DOD has been observed and compared to VES16 lithium-ion cell results. Manufactured on a mass production industrial line, this cell is well suited for low cost missions (eg. Mega Constellations...).

The article will thus present the whole LEO cycling results available for the two cells, and will provide afterwards the correlation status of Saft Li-ion Model (SLIM) with all the experimental data acquired.

Keywords: DOD: Depth of Discharge; OCV: Open Circuit Voltage; EOCV: End Of Charge Voltage; EODV: End Of Discharge Voltage; GEO: Geosynchronous Orbit; IR: Internal Resistance; LEO: Low Earth Orbit; MEO: Medium Earth Orbit; SLIM: Saft Li-Ion Model; SoC: State of Charge.

\section{VES16 LITHIUM-ION CELLS LEO LIFE- TIME TESTS RESULTS}

This chapter focuses on the analysis of the life-test results performed in accelerated (A) or in real time (RT) mode according to VES16 lithium-ion cells LEO lifetests program described in Tab.1.

\begin{tabular}{|c|c|c|c|c|}
\hline Life- & Tests & Condit & & Cycle \\
\hline Mode & EOCV & DOD & TEMP & done \\
\hline Acceler. & $4.05 \mathrm{~V}$ & $20 \%$ & $20^{\circ} \mathrm{C}$ & 37400 \\
\hline Acceler. & $4.05 \mathrm{~V}$ & $30 \%$ & $20^{\circ} \mathrm{C}$ & 33720 \\
\hline $\begin{array}{l}\text { Real } \\
\text { Time }\end{array}$ & $4.05 \mathrm{~V}$ & $20 \%$ & $20^{\circ} \mathrm{C}$ & 27000 \\
\hline $\begin{array}{l}\text { Real } \\
\text { Time }\end{array}$ & $4.05 \mathrm{~V}$ & $20 \%$ & $30^{\circ} \mathrm{C}$ & 25000 \\
\hline $\begin{array}{l}\text { Real } \\
\text { Time } \\
\end{array}$ & $3.9 \mathrm{~V}$ & $20 \%$ & $20^{\circ} \mathrm{C}$ & 27000 \\
\hline $\begin{array}{l}\text { Real } \\
\text { Time }\end{array}$ & $4.05 \mathrm{~V}$ & $30 \%$ & $20^{\circ} \mathrm{C}$ & 27000 \\
\hline $\begin{array}{l}\text { Real } \\
\text { Time } \\
\end{array}$ & 4.05V & $30 \%$ & $30^{\circ} \mathrm{C}$ & 15500 \\
\hline $\begin{array}{l}\text { Real } \\
\text { Time }\end{array}$ & $4.05 \mathrm{~V}$ & $\begin{array}{l}10 \% \\
15 \% \\
20 \%\end{array}$ & $10^{\circ} \mathrm{C}$ & 15000 \\
\hline $\begin{array}{l}\text { Real } \\
\text { Time }\end{array}$ & $4.05 \mathrm{~V}$ & $20 \%$ & $20^{\circ} \mathrm{C}$ & 15000 \\
\hline $\begin{array}{l}\text { Real } \\
\text { Time }\end{array}$ & $4.05 \mathrm{~V}$ & $40 \%$ & $20^{\circ} \mathrm{C}$ & 15500 \\
\hline $\begin{array}{l}\text { Real } \\
\text { Time }\end{array}$ & $\begin{array}{c}C / 3 \\
4.05 V\end{array}$ & $20 \%$ & $5^{\circ} \mathrm{C}$ & 3500 \\
\hline $\begin{array}{l}\text { Real } \\
\text { Time }\end{array}$ & 4.075V & $20 \%$ & $20^{\circ} \mathrm{C}$ & 15500 \\
\hline $\begin{array}{l}\text { Real } \\
\text { Time } \\
\end{array}$ & $4.1 \mathrm{~V}$ & $20 \%$ & $20^{\circ} \mathrm{C}$ & 15500 \\
\hline $\begin{array}{l}\text { Real } \\
\text { Time }\end{array}$ & $\begin{array}{c}\mathrm{C} / 5, \mathrm{C} / 3, \\
\mathrm{C} / 2.5, \mathrm{C} / 2 \\
4.05 \mathrm{~V}\end{array}$ & $20 \%$ & $20^{\circ} \mathrm{C}$ & 12500 \\
\hline $\begin{array}{l}\text { Real } \\
\text { Time }\end{array}$ & $4.05 \mathrm{~V}$ & $50 \%$ & $20^{\circ} \mathrm{C}$ & 3500 \\
\hline
\end{tabular}

Table 1: VES16 Li-ion cells On-Going LEO Life-Tests Program 
These LEO Life-Test results have permitted to assess the influence of the cycling parameters such as DOD/charge current, EOCV and temperature on the evolution of the cell electrical characteristics such as EODV, Capacity, Internal Resistance and Energy, as presented in the following paragraphs.

The evolution of these cell electrical characteristics is measured through a check-up sequence, involving a residual discharge and a reference test at 4.1 Volts a $20^{\circ} \mathrm{C}$, performed at 500 cycles, then every 1000 cycles.

This reference test is based on charge up to $4.1 \mathrm{~V}$, then a discharge down to $2.7 \mathrm{~V}$ under $\mathrm{C} / 2$ discharge rate @ $20^{\circ} \mathrm{C}$ with pulses $1.5 \mathrm{C}-30$ seconds at $20 \& 60 \% \mathrm{DOD}$. It allows also demonstrating the correlation of the LEO life-test results with the SLIM V3 ageing prediction model.

\subsection{EOC Voltage Influence}

The evaluation of the EOCV impact on the VES16 cell behaviour is performed from the results obtained in LEO cycling at $20 \% \mathrm{DOD}-@ 20^{\circ} \mathrm{C}$.

That is done on QM2/QM3 cells in the EOC Voltage range from 3.9 to $4.05 \mathrm{Volts}$, then on FM3 cells in the EOC Voltage range from 4.05 to 4.1 Volts.

After respectively 25000 cycles on QM3 cells \& 27000 cycles on QM2 cells in LEO cycling at $20 \% \mathrm{DOD}$, no significant effect of EOCV between $3.9 \& 4.05 \mathrm{Volts}$ on EOD Voltage variation slope and IR0\%DOD increase, as presented in Figure 1 and 2.

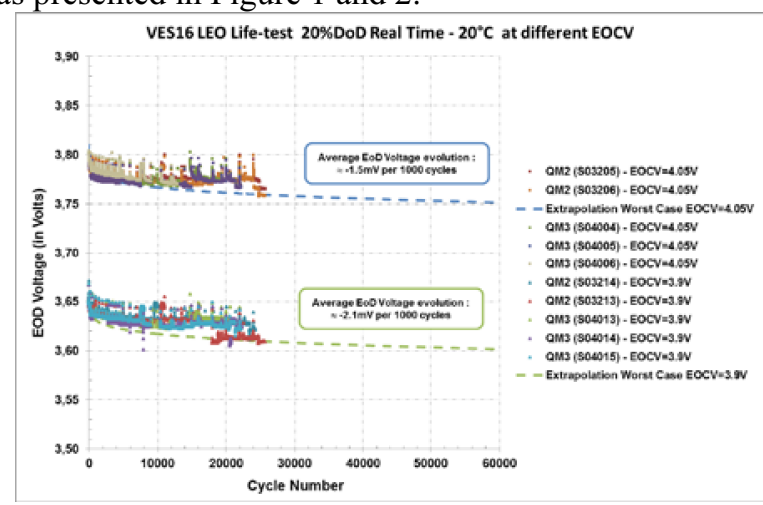

Figure 1. EOD Voltage evolution vs. EOCV \& Cycle Number

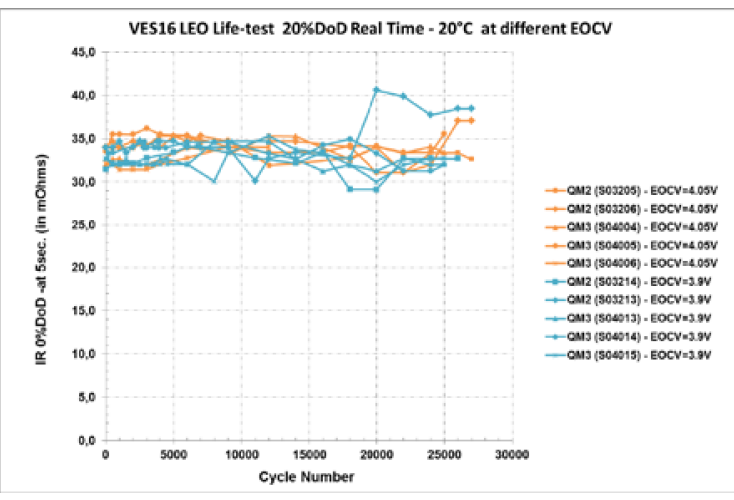

Figure 2. Internal Resistance vs. EOCV \& Cycle Number
We can just note that capacity loss is reduced by $4 \%$ (i.e. $6 \%$ after extrapolation at 60000 cycles) when EOC Voltage is limited to 3.9 Volts, refer to Fig. 3. However, the available capacity is reduced by $9 \%$ due to the limitation of SOC $(\approx 15 \%)$ between $\mathrm{EOCV}=4.05$ and 3.9Volts.

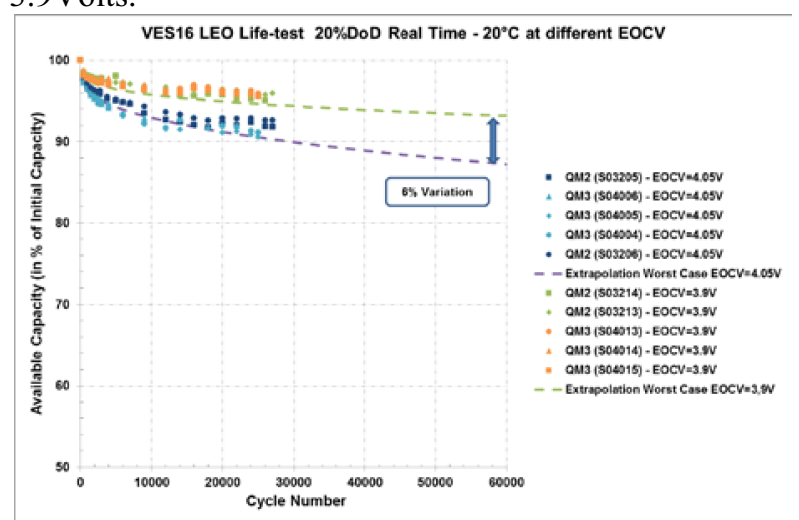

Figure 3. Available capacity vs. EOCV \& Cycle Number

After 15500 cycles in LEO cycling at 20\%DOD on FM3 cells, no significant effect of EOCV between 4.05 \& 4.1Volts has been observed on EOD Voltage variation slope, as presented in Figure 4.

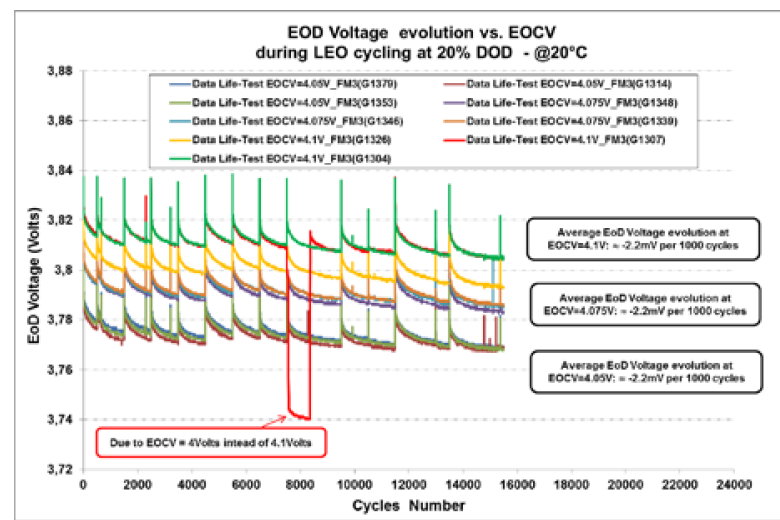

Figure 4. EOD Voltage evolution vs. EOCV \& Cycle Number

Negligible variation observed on Capacity/Energy losses (less than 1\%) and on IR at $20 \%$ \& $60 \%$ DOD increase, as presented in Fig. 5, 6, 7 and 8.

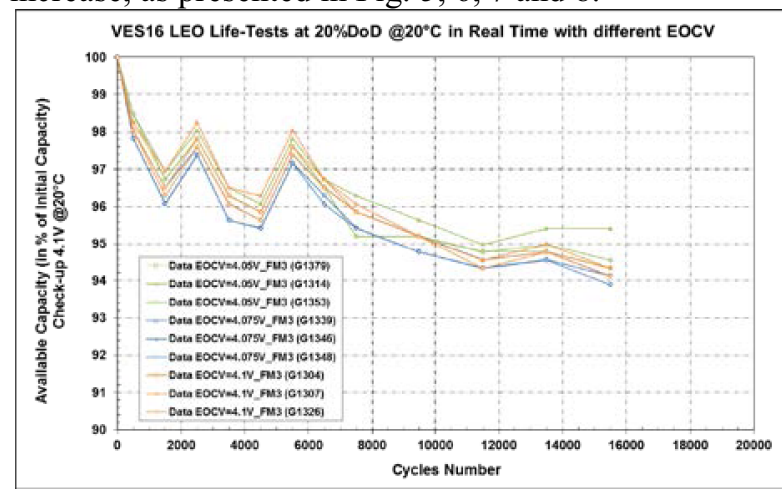

Figure 5. Available capacity vs. EOCV \& Cycle Number 


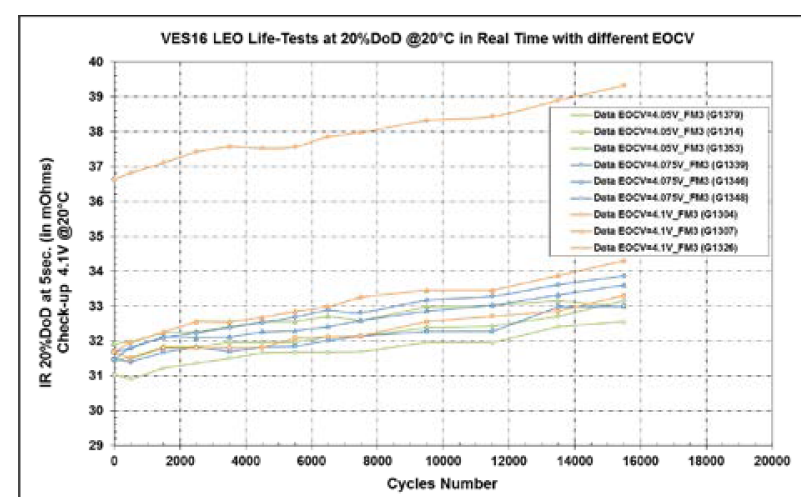

Figure 6. IR 20\%DOD - 5sec. vs. EOCV \& Cycle Number

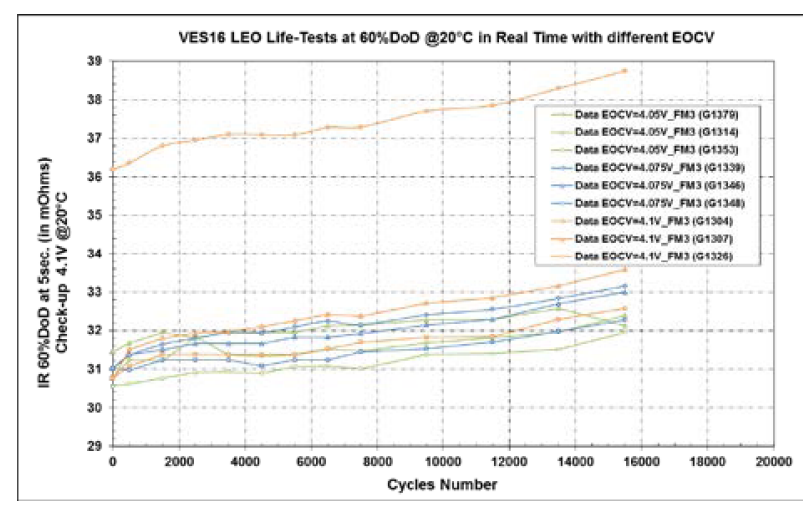

Figure 7. IR 60\%DOD - 5sec. vs. EOCV \& Cycle Number

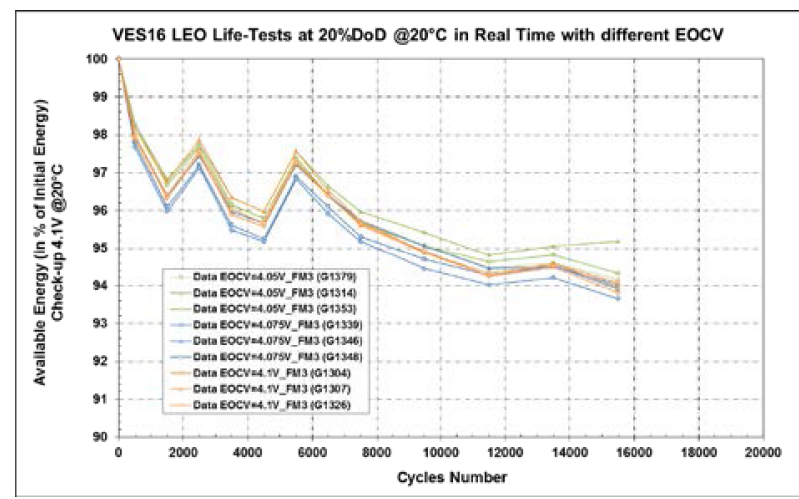

Figure 8. Available energy vs. EOCV \& Cycle Number

\subsection{DOD \& Charge Current Influence}

The evaluation of DOD \& charge current impact on the VES16 cell behaviour is performed from the results obtained in LEO cycling at EOCV=4.05Volts - @ $20^{\circ} \mathrm{C}$.

That is done on QM2/QM3 cells within DOD range from 20 to $30 \%$, then on FM cells within DOD range from $20 \%$ to $50 \%$.

In LEO cycling conditions, DOD \& charge current change together. That comes from the fact that the charge duration is limited and requires to compensate DOD increase by a higher charge current, as presented in Table 2.

\begin{tabular}{|c|c|c|}
\hline DOD (\%) & $\begin{array}{c}\text { Current } \\
(\text { Amps) }\end{array}$ & $\begin{array}{c}\text { Maximum Duration } \\
\text { (minutes) }\end{array}$ \\
\hline 20 & $\mathrm{C} / 5$ & 65 \\
\hline 30 & $\mathrm{C} / 3$ & 65 \\
\hline 40 & $\mathrm{C} / 2.5$ & 65 \\
\hline 50 & $\mathrm{C} / 2$ & 65 \\
\hline
\end{tabular}

Table 2: Charge conditions vs. DoD

After respectively 27000 cycles on QM2 and 25000 cycles on QM3 cells in LEO cycling at $\mathrm{EOCV}=4.05$ Volts $@ 20^{\circ} \mathrm{C}$, a very limited EOD voltage evolution slope increase is observed from $-1.5 \mathrm{mV}$ to $1.6 \mathrm{mV}$ per 1000 cycles between $20 \%$ \& $30 \% \mathrm{DoD}$, as presented in Fig. 9.

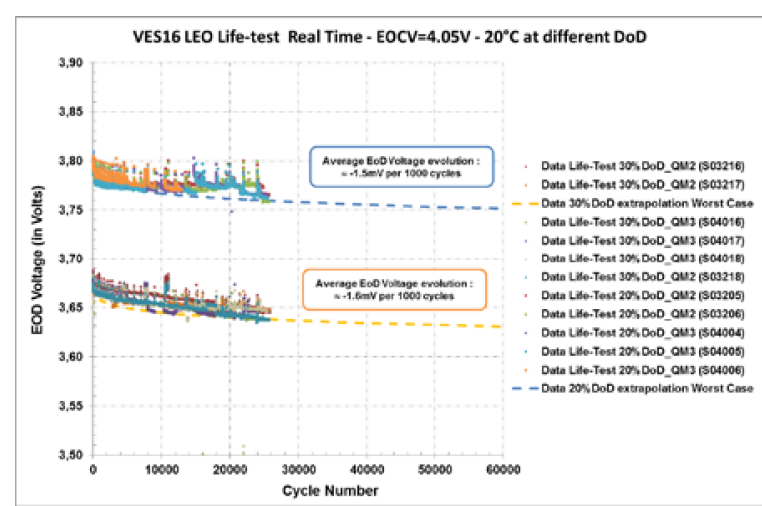

Figure 9. EOD Voltage evolution vs. DOD \& Cycle

Higher capacity loss is observed when DoD increases, $\approx 1.5 \%$ between $20 \% \& 30 \%$ DoD after respectively 27000 cycles on QM2 cells \& 25000cycles on QM3 cells, and $\approx 2 \%$ expected at 60000 cycles, as presented in Fig. 10.

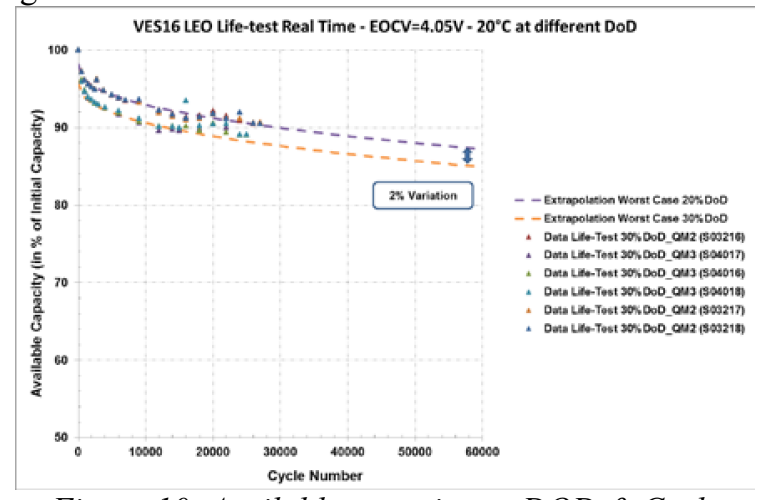

Figure 10. Available capacity vs. DOD \& Cycle Number

No visible effect of DOD \& charge current increase on the QM2/QM3 cells internal resistance, as presented in Fig. 11. 


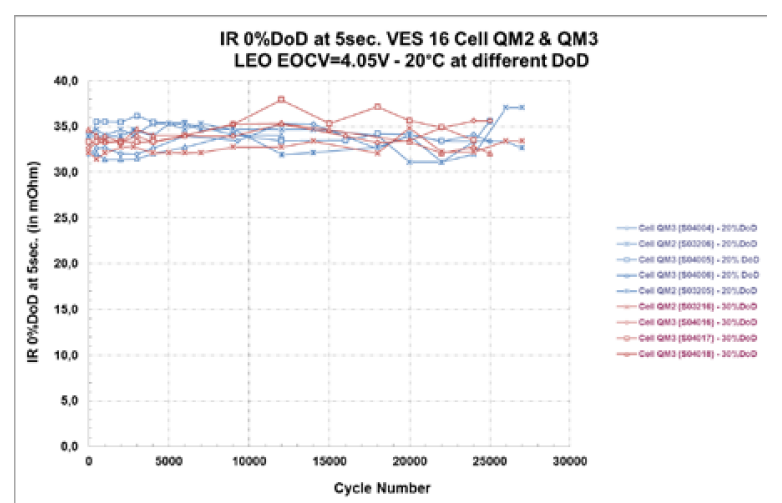

Figure 11. Internal Resistance vs. DOD \& Cycle Number

After respectively 15500 cycles on FM cells in LEO cycling at $\mathrm{EOCV}=4.05$ Volts @ $20^{\circ} \mathrm{C}$, significant EOD voltage evolution slope increase from -2.2 to $-3.5 \mathrm{mV}$ per 1000 cycles between $20 \%$ \& 40\%DOD, as presented in Fig. 12.

Promising results are observed on FM cells in LEO cycling at $50 \%$ DoD with EOD voltage evolution slope which stabilizes from 1500 cycles, as shown in Fig. 12.

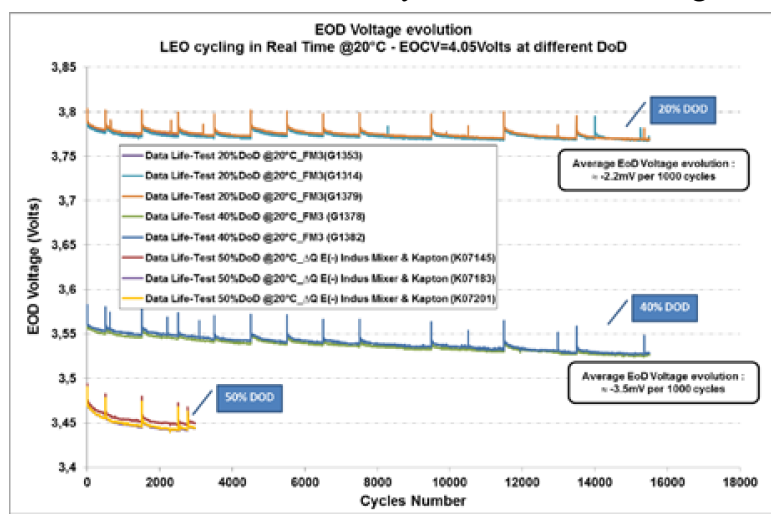

Figure 12. EOD Voltage evolution vs. DOD \& Cycle

Higher energy/capacity losses are observed when DOD increases, $\approx 4 \%$ between $20 \% \& 40 \%$ DOD after 15500 cycles and $\approx 2 \%$ between $40 \%$ \& $50 \%$ DOD after 3500 cycles, as presented in Fig. 13 and 14.

At 60000 cycles, these energy/capacity losses should be less than about $9 \%$ between $20 \% \& 40 \%$ DoD and less than about $7 \%$ between $40 \%$ \& $50 \%$ DoD.

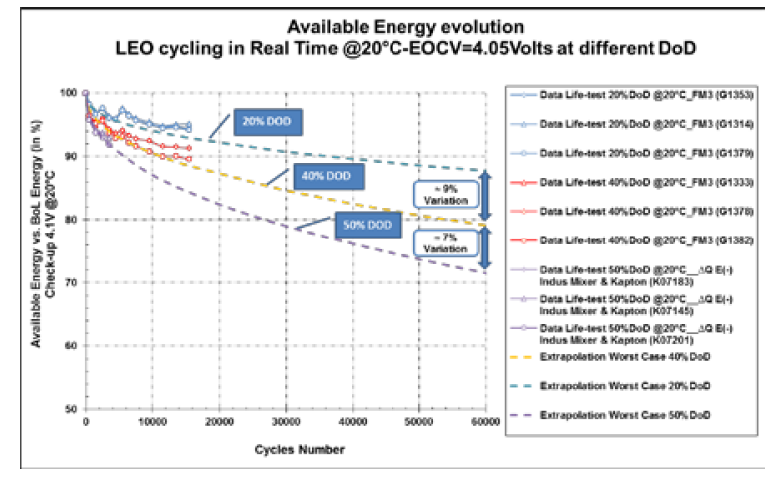

Figure 13. Available energy vs. DOD \& Cycle Number

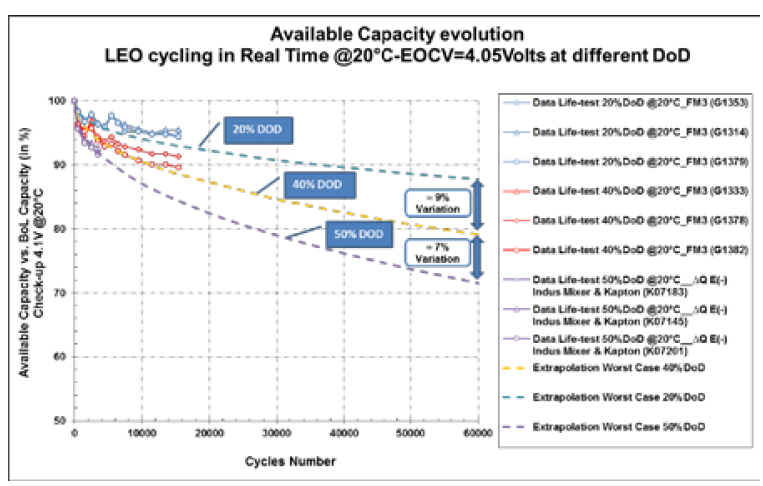

Figure 14. Available capacity vs. DOD \& Cycle Number

No visible effect of DOD \& charge current increase on FM cells internal resistance evolution, as presented in Fig. 15 and 16.

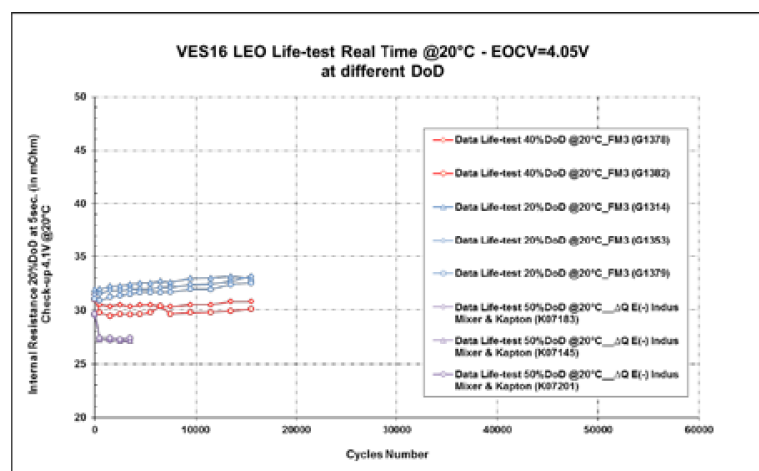

Figure 15. IR 20\%DOD vs. DOD \& Cycle Number

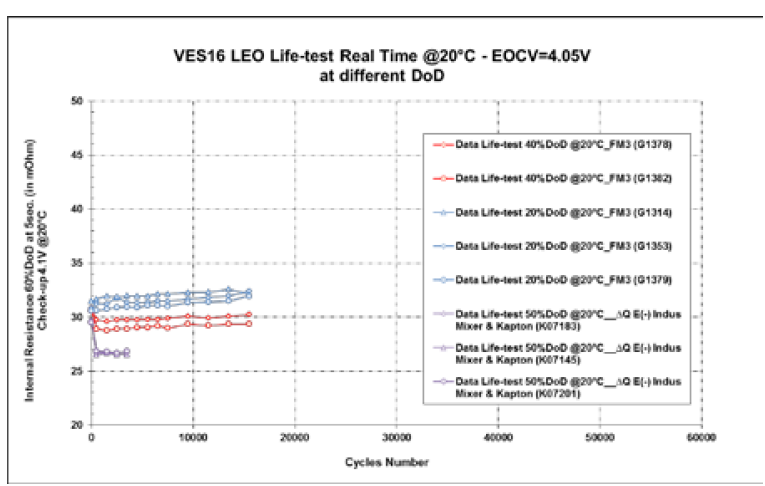

Figure 16. IR 60\%DOD vs. DOD \& Cycle Number

\subsection{Temperature Influence}

The evaluation of temperature impact on the VES16 cell behaviour is performed from the results obtained in LEO cycling at EOCV $=4.05$ Volts $-20 \% \mathrm{DO}$.

That is done on QM2/QM3 cells within the temperature range from 20 to $30^{\circ} \mathrm{C}$, then on $\mathrm{FM}$ cells within the temperature range from 5 to $20^{\circ} \mathrm{C}$.

After respectively 20000 cycles on QM2 cells \& 25000 cycles on QM3 cells in LEO cycling at $\mathrm{EOCV}=4.05$ Volts $-20 \% \mathrm{DOD}$, weak EOD voltage evolution slope increase is observed from $-1.5 \mathrm{mV}$ to - 
$2.3 \mathrm{mV}$ per 1000 cycles between $20^{\circ} \mathrm{C} \& 30^{\circ} \mathrm{C}$, as presented in Fig. 17.

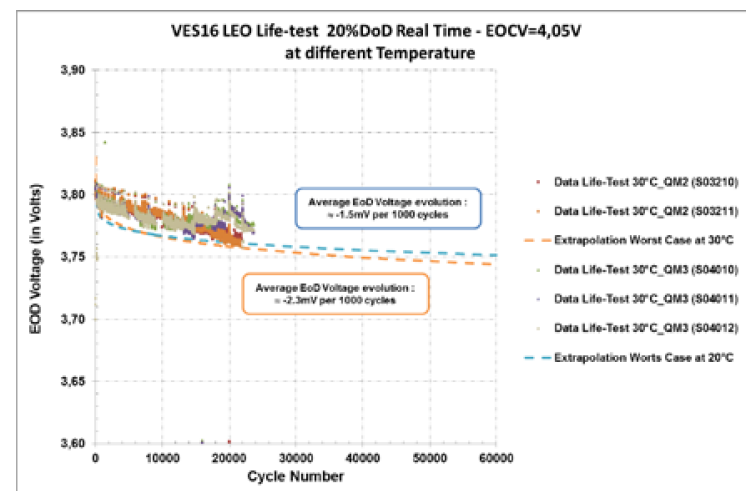

Figure 17. EOD Voltage evolution vs. Temp. \& Cycle Number

When the temperature increases from $20^{\circ} \mathrm{C}$ to $30^{\circ} \mathrm{C}$, higher capacity loss is observed, $\approx 4 \%$ after respectively 20000 cycles on QM2 cells \& 25000cycles on QM3 cells, and $\approx 7 \%$ expected at 60000 cycles, as presented in Fig. 18.

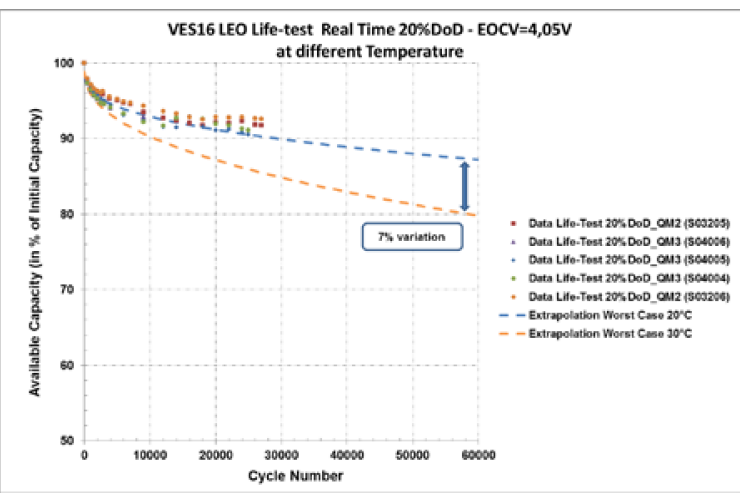

Figure 18. Available capacity vs. Temp. \& Cycle

$$
\text { Number }
$$

No visible effect of DOD \& charge current increase on QM2/QM3 cells internal resistance, as presented in Fig. 19.

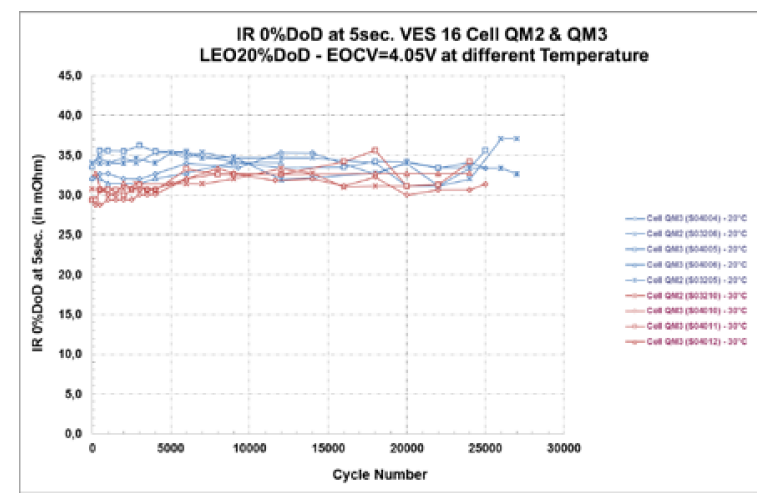

Figure 19. Internal Resistance vs. Temp. \& Cycle Number

After 15000 cycles on FM3 cells in LEO cycling at $\mathrm{EOCV}=4.05$ Volts $-20 \% \mathrm{DOD}$, the same EOD voltage evolution slope is observed at $10^{\circ} \mathrm{C} \& 20^{\circ} \mathrm{C}$, about $2.4 \mathrm{mV}$ per 1000 cycles, as presented in Fig. 20.

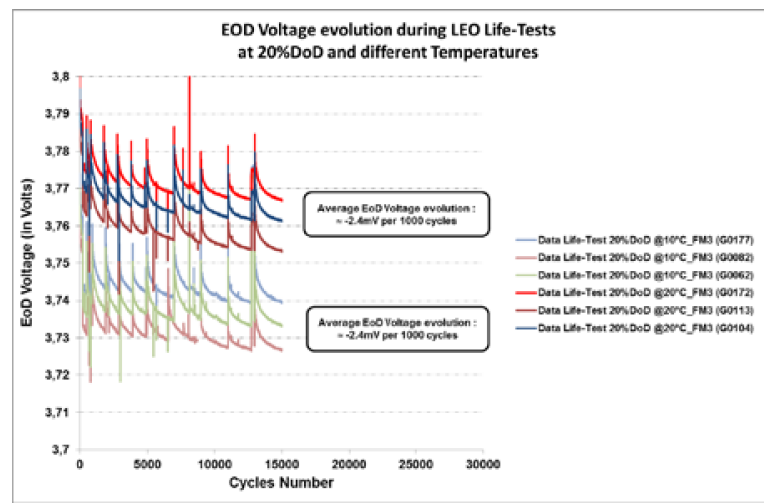

Figure 20. EOD Voltage evolution vs. Temp. \& Cycle Number

No significant capacity/energy losses are also measured within the temperature range from $10^{\circ} \mathrm{C}$ to $20^{\circ} \mathrm{C}$, as presented in Fig. 21 and 22.

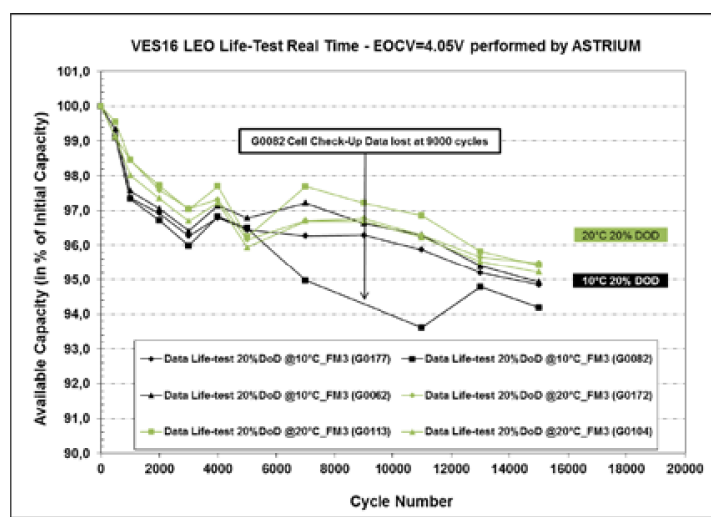

Figure 21. Available capacity vs. Temp. \& Cycle Number

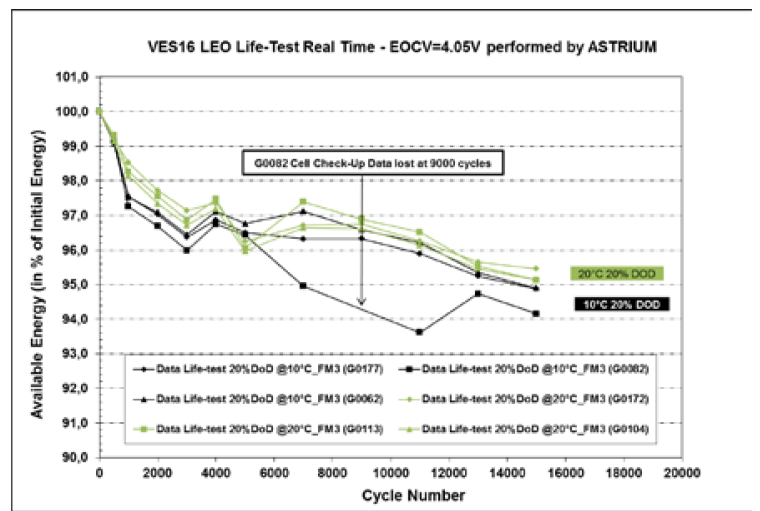

Figure 22. Available energy vs. Temp. \& Cycle Number

No more visible effect of the temperature between $10^{\circ} \mathrm{C}$ $\& 20^{\circ} \mathrm{C}$ on the FM3 cells internal resistance evolution, as presented in Fig. 23 and 24. 


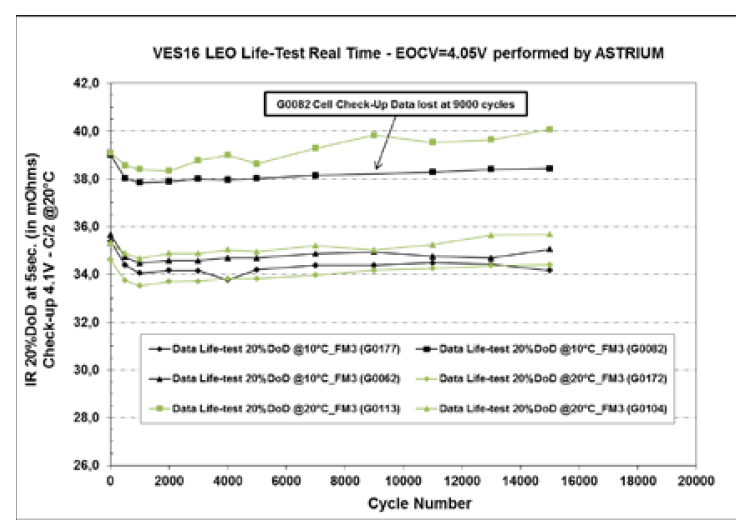

Figure 23. IR 20\%DOD vs. Temp. \& Cycle Number

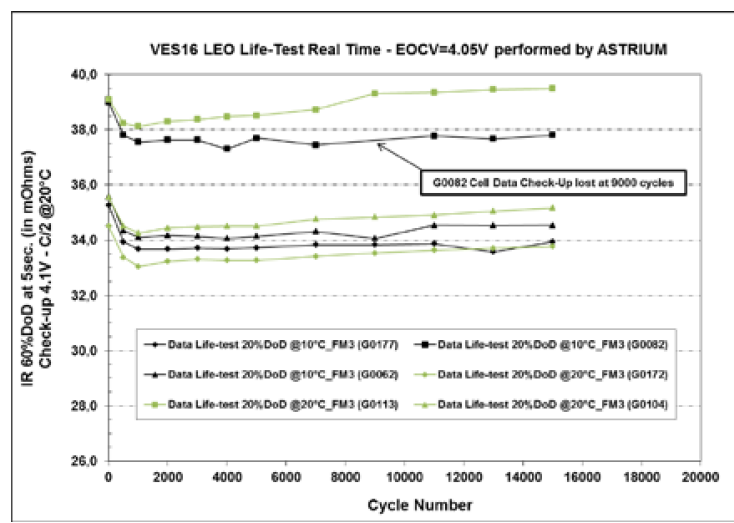

Figure 24. IR 60\%DOD vs. Temp. \& Cycle Number

After 3500 cycles on FM cells in LEO cycling at EOCV $=4.05$ Volts $-20 \% \mathrm{DOD}$ with $\mathrm{C} / 3$ charge current, the EOD voltage evolution slopes observed at $+5^{\circ} \mathrm{C}$ \& $+20^{\circ} \mathrm{C}$ are very similar, respectively -5.4 and $-5.1 \mathrm{mV}$ per 1000 cycles, as presented in Fig. 25.

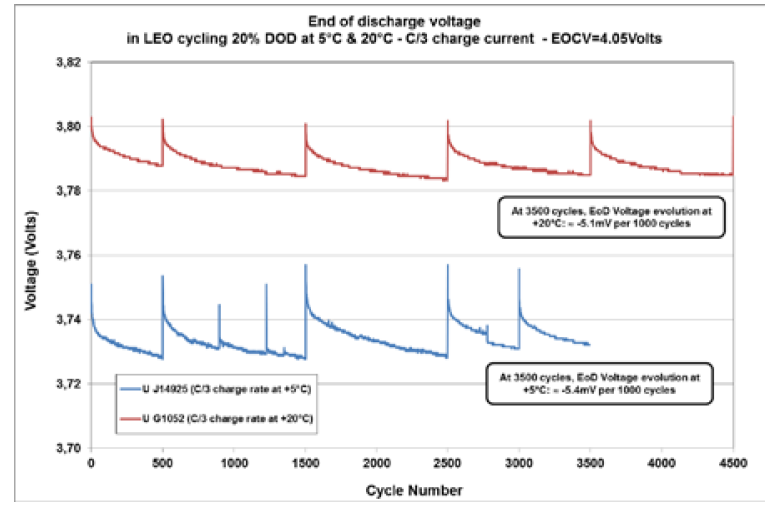

Figure 25. EOD Voltage evolution vs. Temp. \& Cycle Number

No significant capacity/energy losses are also measured within the temperature range from $+5^{\circ} \mathrm{C}$ to $+20^{\circ} \mathrm{C}$, as presented in Fig. 26 and 27.

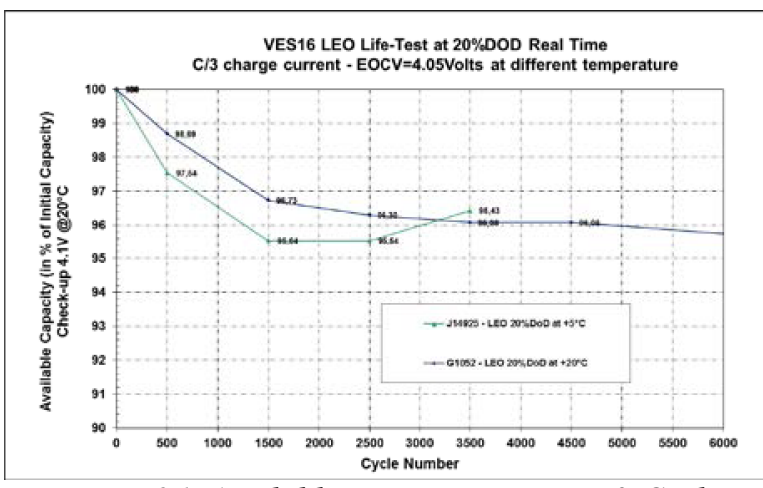

Figure 26. Available capacity vs. Temp \& Cycle Number

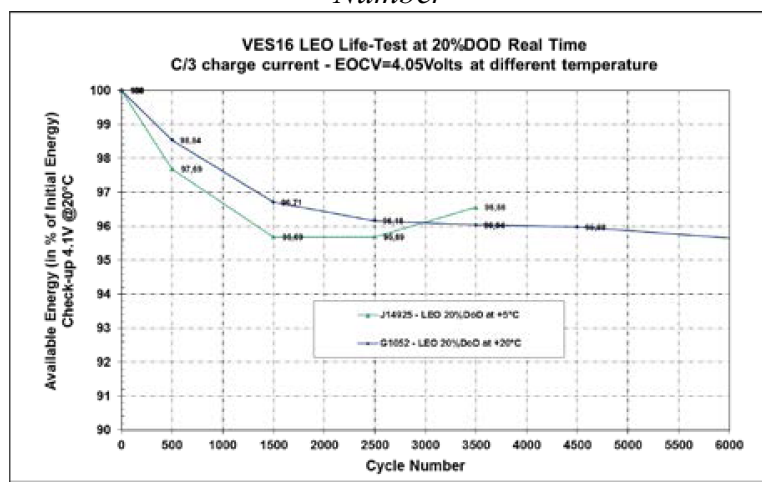

Figure 27. Available energy vs. Temp \& Cycle Number

No more visible effect of the temperature between $+5^{\circ} \mathrm{C}$ $\&+20^{\circ} \mathrm{C}$ on the FM cells internal resistance evolution, as presented in Fig. 28 and 29.

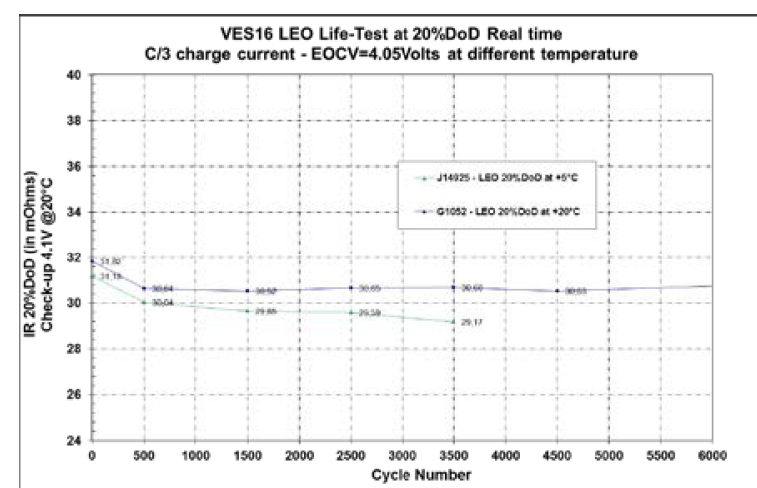

Figure 28. IR 20\%DOD vs. Temp. \& Cycle Number

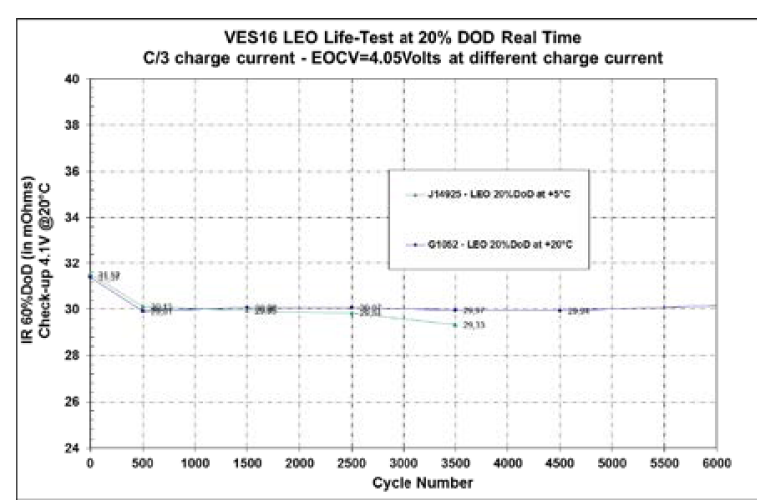

Figure 29. IR 60\%DOD vs. Temp. \& Cycle Number 


\subsection{SLIM Correlation based on LEO Life-Test Results}

SLIM is a macroscopic electrochemical model based on energy. Its main purpose is to predict the VES and MPS cell performances during the life for GEO, MEO and LEO missions.

This model is based on electrochemical characteristics such as Energy, Capacity, EMF, Internal resistance, EOCV. It uses fading and calendar law effects on energy and internal impedance vs. time, temperature, End of Charge voltage. The degradation mechanisms at electrode levels have been set up based on the Destructive Physical Analyses that were focused on the electrochemical changes. The model is also able to deliver the battery performances using mission figures and profiles.

SLIM V3 correlation has been done from 30\%DOD LEO cycling Life-test conditions involving:

- Charge at $\mathrm{C} / 3$ constant current up to 4.05 Volts, then tapering up to $\mathrm{I}=20 \mathrm{~mA}$ or maximum duration $=65$ minutes.

- Discharge at 2.31 Amps during 35 minutes equivalent to $1.35 \mathrm{Ah}$ discharged.

As shown in Fig. 30, the EOD voltages measured or extrapolated are much higher than the predicted ones, around $15 \mathrm{mV}$ after 25000 cycles on QM3, $25 \mathrm{mV}$ after 27000 cycles on QM2, and $50 \mathrm{mV}$ at 50000 cycles.

As presented in Fig. 31, the available capacity calculated by SLIM V3 fits at less $6 \%$ with the worst case $30 \%$ DoD LEO life-tests data after 50000 cycles.

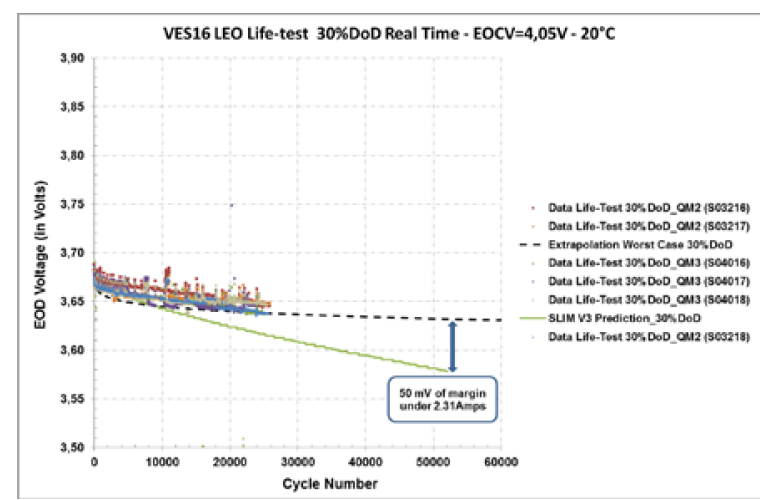

Figure 30. EOD Voltage evolution vs. SLIM V3 ageing model

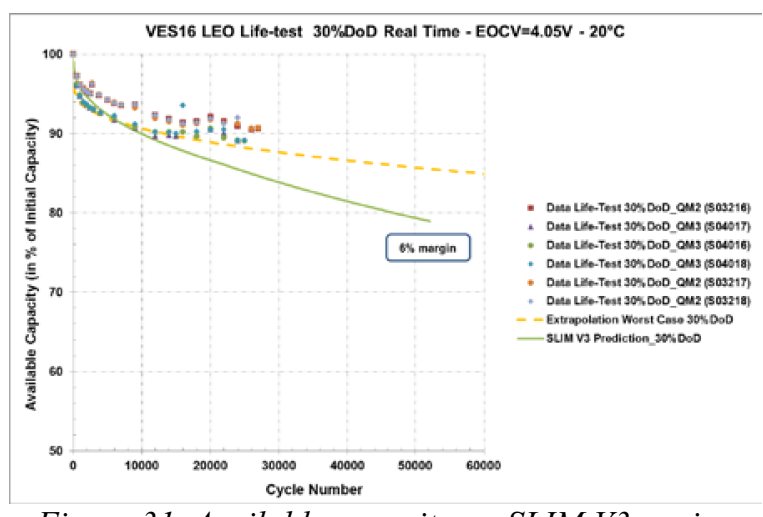

Figure 31. Available capacity vs. SLIM V3 ageing model

\subsection{Conclusion}

VES16 Li-ion cell electrical performances evolution observed in LEO Life-tests is excellent in the whole range of DOD up to $50 \%$, with EOC voltage in the range from 3.9 to $4.1 \mathrm{~V}$ and with a temperature in the range from $5^{\circ} \mathrm{C}$ to $30^{\circ} \mathrm{C}$.

That can be explained by the very good ability of the negative electrode design to sustain LEO cycling conditions with larger charge current up to $2.57 \mathrm{Amps}$ and lower temperature down to $0^{\circ} \mathrm{C}$.

$\mathrm{Up}$ to 50000 cycles, the error between the available capacity/EODV predicted by SLIM V3 ageing model and the ones extrapolated from the LEO life-tests data at $30 \%$ DOD are respectively less than $50 \mathrm{mV} \& 6 \%$.

\section{MP176065 XTD LITHIUM-ION CELLS LEO LIFE-TIME TESTS RESULTS}

New MP176065 XTD Lithium-ion cell presents promising results in accelerated LEO cycling conditions at $30 \%$ DOD, comparable to VES16 lithium-ion cell ones. We can even observe a lower capacity loss of $\approx 4 \%$ after 6000 cycles, as shown in Fig. 32 .

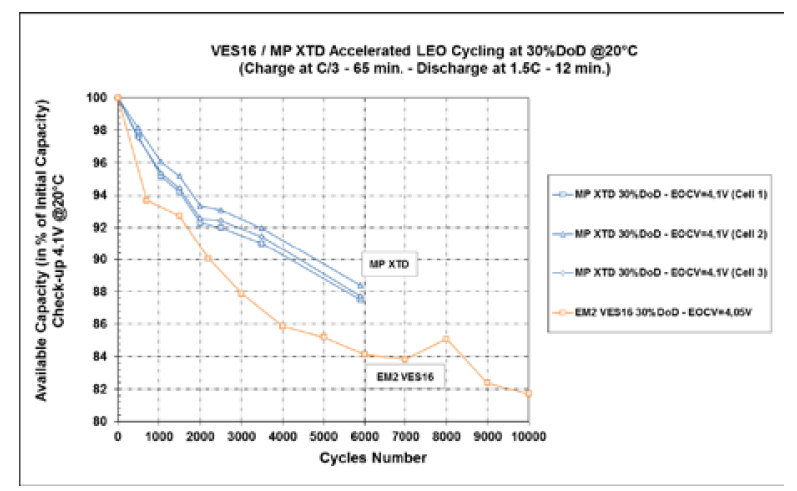

Figure 32. MP176065 XTD / VES16 available capacity evolution in accelerated LEO cycling at $30 \% D O D$ 


\section{CONCLUSION}

The excellent results, observed on VES16 Li-ion cell in LEO Lifetime tests, allow to foreseen its use for LEO mission up to 12 years or more, depending on DOD.

New MP176065 XTD Lithium-ion cell presents promising results in accelerated LEO cycling conditions at $30 \%$ DOD. However, its lifetime database shall be strengthened to assess and to validate its space use in LEO missions.

\section{REFERENCES}

[1]9th ESPC 2011, Article 2103465 / Session 3: Cells and Batteries Design , "VES16 Li ion cell for satellite" S. Rémy, D. Prevot, D. Reulier \& Dr. F. Vigier

[2]9th ESPC 2011, Article 2103465 / Session 23: Battery Management - Modelling, "SLIM Battery Modelling Features" - Y. Borthomieu, D. Prevot

[3]10th ESPC 2014, Article S14-1 / Session 14: Battery Experience and modelling, "VES16 Lithium-ion cell lifetime tests results \& SLIM correlation" - D. Prevot, Y. Borthomieu \& C. Cenac-Morthe 